
MANAGEMENT, AND ACCOUNTING

Fakultas Ekonomi Universitas Andi Djemma

Jl. Puang H. Daud No 4 Kota Palopo

\title{
Pengaruh Due Professional Care dan Akuntabilitas Auditor terhadap Kualitas Audit
}

\author{
Penulis \\ Nurfadilah ${ }^{1}$ \\ Dosen Program Studi Manjemen Bisnis \\ Syariah \\ Institut Agama Islam Negeri (IAIN) Palopo \\ Email: fadilahaktx@gmail.com
Nurhuda ${ }^{2}$
Dosen Program Studi Ekonomi Pembangunan Universitas Andi Djemma
Email: airinnurhuda@gmail.com

\author{
Info Artikel \\ p-ISSN : 2615-1871 \\ e-ISSN : 2615-5850 \\ Volume 3 Nomor 1, Maret 2020 \\ DOI: \\ http://dx.doi.org/10.35914/jemma.v3i1.325 \\ Article History:
Received, 3 Februari 2020
Revised, 15 Februari 2020
Accepted, 16 Maret 2020
}

\begin{abstract}
ABSTRAK
Pengaruh Due Professional Care dan Akuntabilitas Auditor terhadap Kualitas Audit.Penelitian ini bertujuan untuk menganalisis dan memberikan bukti empiris pengaruh Due Professional Care dan Akuntabilitas Auditor Terhadap Kualitas Audit. Penelitian ini menggunakan metode analisis statistik deskriptif dan regresi linear berganda dengan penggunaan Program SPSS. Sampel yang digunakan berdasarkan semua jumlah populasi auditor pada Kantor Inspektorat Provinsi Sulawesi Selatan yaitu 47 auditor. Metode pengumpulan data penelitian dilakukan dengan metode kuesioner. Hasil penelitian ini menunjukan bahwa due professional care dan akuntabilitas auditor berpengaruh positif dan signifikan terhadap kualitas audit baik secara parsial maupun simultan.
\end{abstract}

Kata Kunci : Akuntabilitas, Due Professional Care, Kualitas Audit.

\section{PENDAHULUAN}

Tuntutan akuntabiltas pada sektor publik atas terwujudnya good governance di Indonesia semakin meningkat. Beberapa peneliti mengemukakan terjadinya krisis ekonomi di Indonesia disebabkan karena buruknya tata kelola (bad governance) dan buruknya birokrasi. Terwujudnya akuntabilitas sektor publik dan good governance, diperlukan adanya pemeriksaan oleh pihak yang berkompeten. Pihak-pihak yang berkompeten yaitu internal auditor pemerintah (Inspektorat) dan eksternal auditor Badan Pemeriksa Keuangan (BPK).

Aparat inspektorat bertugas untuk melaksanakan audit terhadap laporan keuangan dan memberikan suatu pendapat apakah laporan keuangan tersebut menyajikan secara wajar, dalam semua hal yang material, posisi keuangan, dan hasil usaha entitas sesuai dengan Standar Akuntansi Keuangan (Munawaroh, 2019). Inspektorat merupakan sumber informasi yang penting bagi auditor BPK serta menjadi ujung tombak transparansi dan akuntabilitas pengelolaan keuangan daerah. Sebab hasil audit yang berkualitas merupakan sumber informasi penting dalam memberikan keyakinan kepada pihak pemerintah, DPRD dan BPK. Pengelolaan keuangan pemerintah yang baik harus didukung audit sektor publik yang berkualitas, jika 
kualitas audit pada sektor publik rendah, kemungkinan memberikan kelonggaran terhadap aparatur pemerintah melakukan penyimpangan pengelolaan anggaran. Selain itu juga dapat menyebabkan risiko tuntutan hukum terhadap aparatur pemerintah yang melaksanakannya.

Audit sektor publik merupakan elemen penting dalam penegakan good governance. Namun dalam praktiknya sering jauh dari apa yang diharapkan. Terdapat beberapa kelemahan yang terjadi dalam audit pemerintahan di Indonesia seperti, tidak tersedianya indikator kinerja yang memadai sebagai dasar pengukur kinerja pemerintahan baik pemerintah pusat maupun daerah. Hal tersebut umum dialami oleh organisasi sektor publik karena output yang dihasilkan berupa pelayanan publik yang sulit terukur.

Untuk meningkatkan kualitas audit, BPK telah menerbitkan Standar Pemeriksaan Keuangan Negara (SPKN) sesuai dengan Peraturan Badan Pemeriksa Keuangan Republik Indonesia No.1 Tahun 2017 dalam kaitannya sebagai pemeriksa eksternal keuangan negara, auditor dalam melaksanakan tugasnya perlu dilandasi dengan sikap, etika, dan moral yang baik sehingga auditor dapat menjalankan tugas dan kewajibannya secara objektif (Anderson dan Ellyson, 1986 dalam Nugraha, 2010).

Internal auditor dalam menjalankan tugasnya harus mempunyai keahlian dan due professional care. Seperti dinyatakan dalam Pernyataan Standar Auditing (SPAP, 2001 : 150.1) adalah keahlian dan due professional care yang memiliki arti sikap yang cermat dan seksama. Menurut PSA No. 4 SPAP (2001) kecermatan dan keseksamaan menuntut auditor untuk melaksanakan skeptisme professional, yaitu sikap auditor berpikir kritis terhadap auditi dengan selalu mempertanyakan dan melakukan evaluasi terhadap bukti audit tersebut. Hasil penelitian Putri Arsika dan Nur Cahyonowati (2013) membuktikan bahwa auditor yang mengimplementasikan due professional care dengan baik dalam melaksanakan pekerjaan auditnya, maka audit yang dihasilkan akan makin berkualitas. Penggunaan kemahiran profesional dengan cermat dan seksama memungkinkan auditor untuk memperoleh keyakinan memadai bahwa laporan keuangan bebas dari salah saji material, baik yang disebabkan oleh kekeliruan maupun kecurangan.

Selain itu, kualitas audit dapat dipengaruhi oleh rasa kebertanggungjawaban (akuntabilitas) yang dimiliki auditor dalam menyelesaikan pekerjaan audit. Dalam Pernyataan Standar Audit (PSA) No.02 SA Seksi 110 dijelaskan bahwa auditor bertanggungjawab untuk merencanakan audit dan memperoleh keyakinan yang memadai tentang apakah laporan keuangan bebas dari salah saji yang material, baik yang disebabkan oleh kekeliruan atau kecurangan. hasil penelitian yang dilakukan oleh Putri dan Cahyonowati (2013) bahwa auditor yang memiliki akuntabilitas tinggi akan bertaggung jawab penuh terhadap pekerjaannya, sehigga kualitas audit yang dihasilkan pun akan semakin baik. Dari pernyataan di atas dapat ditarik kesimpulan bahwa semakin besar akuntabilitas seorang auditor maka semakin tinggi tingkat kualitas hasil kerja.

Berdasarkan latar belakang penelitian yang telah diuraikan diatas adapun tujuan dilaksanakannya penelitian ini untuk mengetahui dan menganalisis pengaruh Due professional care dan akuntabilitas auditor terhadap kualitas audit. 


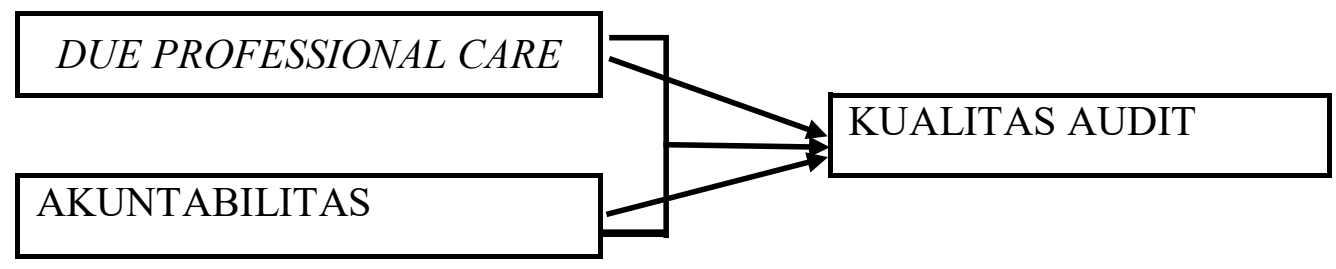

\section{Gambar. 1. Model Penelitian}

\section{METODE PENELITIAN}

\section{Objek Penelitian}

Objek penelitian ini terdiri dari dua variabel, yaitu variabel independen dan variabel dependen. Variabel independen/bebas pada penelitian ini adalah : due professional care auditor dan akuntabilitas auditor. Adapun variabel dependen/terikat dalam penelitian ini adalah kualitas audit. Sehubungan dengan objek penelitian tersebut, maka subjek penelitian ini adalah auditor Inspektorat Provinsi Sulawesi Selatan.

\section{Operasionalisasi Variabel}

Agar penelitian dapat terlaksana sesuai dengan yang diharapkan, maka perlu dipahami berbagai unsur yang menjadi dasar dari suatu penelitian ilmiah yang termuat dalam operasional variable penelitian. Adapun secara rinci operasionalisasi variabel penelitaian sebagai berikut :

\section{Tabel 1. Operasionalisasi Variabel}

\begin{tabular}{|c|c|c|c|c|c|}
\hline No. & Variabel & Konsep Variabel & Indikator & Skala & Item \\
\hline 1. & $\begin{array}{l}\mathrm{X} 1 \\
\text { (Due } \\
\text { Professional } \\
\text { Care) }\end{array}$ & $\begin{array}{l}\text { Due professional care memiliki arti } \\
\text { kemahiran profesional yang cermat } \\
\text { dan seksama. Menurut PSA No. } 4 \\
\text { SPAP (2001), kecermatan dan } \\
\text { keseksamaan dalam penggunaan } \\
\text { kemahiran profesional menuntut } \\
\text { auditor untuk melaksanakan skeptisme } \\
\text { profesional, yaitu suatu sikap auditor } \\
\text { yang berpikir kritis terhadap bukti } \\
\text { audit dengan selalu mempertanyakan } \\
\text { dan melakukan evaluasi terhadap bukti } \\
\text { audit tersebut. }\end{array}$ & $\begin{array}{ll}\text { a. } & \text { Sikap } \\
& \text { skeptis. } \\
\text { b. } & \text { Keyakinan } \\
& \text { yang } \\
& \text { memadai. }\end{array}$ & Odinal & $\begin{array}{l}1-2 \\
3-4\end{array}$ \\
\hline 2. & $\begin{array}{l}\text { X2 } \\
\text { (Akuntabilitas) }\end{array}$ & $\begin{array}{l}\text { Akuntabilitas sebagai bentuk dorongan } \\
\text { psikologi yang membuat seseorang } \\
\text { berusaha mempertanggung- jawabkan } \\
\text { semua tindakan dan keputusan yang } \\
\text { diambil kepada lingkungannya } \\
\text { (tetclock 1984). }\end{array}$ & $\begin{array}{ll}\text { a. } & \text { Motivasi } \\
\text { b. } & \text { Pengabdia } \\
& \text { n pada } \\
& \text { profesi. } \\
\text { c. } & \text { Kewajiban } \\
& \text { sosial. }\end{array}$ & Ordinal & $\begin{array}{r}5-6 \\
7-8 \\
9-11\end{array}$ \\
\hline 3. & $\begin{array}{l}\text { Y } \\
\text { (Kualitas } \\
\text { Audit) }\end{array}$ & $\begin{array}{l}\text { Kualitas audit adalah sebagai } \\
\text { kemungkinan (probability) dimana } \\
\text { seorang auditor menemukan dan } \\
\text { melaporkan tentang adanya suatu } \\
\text { pelanggaran dalam sistem akuntansi } \\
\text { kliennya. (De Angelo;1981). }\end{array}$ & $\begin{array}{ll}\text { a. } & \text { Tepat } \\
\text { Waktu } \\
\text { b. Lengkap } \\
\text { c. Akurat } \\
\text { d. Jelas }\end{array}$ & Ordinal & $\begin{array}{l}12-13 \\
14-16 \\
17-18 \\
19-20\end{array}$ \\
\hline
\end{tabular}




\section{Populasi dan Sampel}

Adapun populasi dalam penelitian ini adalah auditor Inspektorat Provinsi Sulawesi Selatan, yang berjumlah 47 (empat puluh tujuh) orang. Dikarenakan jumlah auditor atau populasi dari tempat penelitian di Inspektorat Provinsi Sulawesi Selatan kurang dari 100 yaitu hanya 47 auditor, maka dalam penelitian ini semua auditor atau populasi dijadikan subjek penelitian. Dengan demikian teknik pengambilan sampel yang digunakan dalam penelitian ini adalah teknik sampling jenuh (sensus).

\section{Jenis dan Sumber Data}

Adapun jenis data yang digunakan dalam penelitian ini adalah data kuantitatif. Sugiyono (2010) kuantitatif adalah penelitian yang dilakukan yang digunakan dengan mengumpulkan jawaban dari responden atau pertanyaan yang merupakan pengukuran dari variabel diteliti.

Sumber data pada penelitian ini merupakan data primer. Data penelitian yang diperoleh secara langsung dari sumber asli (tidak melalui media perantara) yaitu dengan menggunakan kuesioner. Data tersebut berasal dari jawaban responden atas kuesioner yang dibagikan kepada responeden dalam hal ini auditor yang terdaftar dan bekerja di Kantor Inspektorat Provinsi Sulawesi Selatan.

\section{Metode Analisis Data}

Penelitian ini menggunakan analisis statistik deskriptif yang digunakan untuk memberi gambaran umum mengenai demografi responden dalam penelitian dan deskripsi mengenai variabel-variabel penelitian (due professional care, akuntabilitas dan kualitas audit). Analisa data yang dilakukan dengan menggunakan regresi linear berganda. Data yang diperoleh dari penelitian ini adalah data yang dikumpulkan dengan menggunakan kuesioner, sehingga diperlukan dua macam pengujian yaitu : Uji validitas dan uji reliabilitas. Kesahihan (validitas) dan kehandalan (reliabilitas) dalam penelitian ini dilakukan dengan bantuan program SPSS. Sedangkan uji asumsi klasik yang digunakan pada penelitian ini yaitu uji normalitas, uji multikolinearitas, dan uji heteroskedastisitas.

Setelah dilakukan pengujian asumsi-asumsi klasik statistik dan telah terbukti bahwa terbebas dari asumsi-asumsi klasik tersebut, maka data dalam penelitian ini akan dilakukan pengujian kebenaran uji hipotesis. Pengujian hipotesis dilakukan dengan menggunakan model analisis regresi berganda (multiple regression) yang bertujuan untuk memprediksi berapa besar kekuatan pengaruh variabel independen (due professional care dan akuntabilitas) terhadap variabel dependen (kualitas audit) baik secara parsial (t) maupun simultan (F). Persamaan regresinya adalah:

Keterangan:

$$
Y=\beta o+\beta_{1} X_{1}+\beta_{2} X_{2}+e
$$

$$
\begin{array}{ll}
\mathrm{Y} & =\text { Kualitas Audit } \\
\beta \mathrm{o} & =\text { Konstanta } \\
\beta_{1}, \beta_{2} & =\text { Koefisien berganda } \\
\mathrm{X}_{1} & =\text { Due Professional Care } \\
\mathrm{X}_{2} & =\text { Akuntabilitas } \\
\mathrm{e} & =\text { error }(5 \%) \text { dan signifikan }(95 \%)
\end{array}
$$




\section{HASIL DAN PEMBAHASAN}

\section{Uji Kualitas Data}

Validitas menunjukkan sejauh mana alat pengukur yang digunakan mampu untuk mengukur apa yang diukur. Adapun caranya adalah dengan mengkorelasikan antara skor yang diperoleh pada masing-masing item kuesioner dengan skor total individu.

Tabel 2. Hasil Pengujian Validitas

\begin{tabular}{|c|c|c|c|}
\hline Variabel / Indikator & Korelasi & r tabel & Keterangan \\
\hline \multicolumn{4}{|l|}{ Due Professional Care (X1) } \\
\hline 1 & 0,902 & 0,324 & Valid \\
\hline 2 & 0,887 & 0,324 & Valid \\
\hline 3 & 0.865 & 0,324 & Valid \\
\hline 4 & 0,810 & 0,324 & Valid \\
\hline \multicolumn{4}{|l|}{ Akuntabilitas (X2) } \\
\hline 5 & 0,585 & 0,324 & Valid \\
\hline 6 & 0,710 & 0,324 & Valid \\
\hline 7 & 0,741 & 0,324 & Valid \\
\hline 8 & 0,726 & 0,324 & Valid \\
\hline 9 & 0,697 & 0,324 & Valid \\
\hline 10 & 0,720 & 0,324 & Valid \\
\hline 11 & 0,442 & 0,324 & Valid \\
\hline \multicolumn{4}{|l|}{ Kualitas Audit (Y) } \\
\hline 12 & 0,732 & 0,324 & Valid \\
\hline 13 & 0,748 & 0,324 & Valid \\
\hline 14 & 0,808 & 0,324 & Valid \\
\hline 15 & 0,669 & 0,324 & Valid \\
\hline 16 & 0,738 & 0,324 & Valid \\
\hline 17 & 0,546 & 0,324 & Valid \\
\hline 18 & 0,748 & 0,324 & Valid \\
\hline 19 & 0,660 & 0,324 & Valid \\
\hline 20 & 0,646 & 0,324 & Valid \\
\hline
\end{tabular}

Tabel 2 menunjukkan bahwa Indikator - indikator variabel yang digunakan pada penelitian ini semuanya memiliki nilai korelasi yang lebih besar dari 0,324 yaitu $\mathrm{r}$ tabel untuk sampel sebanyak 37 pada taraf signifikansi 95\% $(\alpha=0,05)$ hal ini berarti, bahwa semua indikator penelitian yang digunakan untuk mengukur semua variabel dalam penelitian ini dinyatakan sebagai item yang valid.

\section{Uji Reliabilitas}

Pada penelitan ini pengujian terhadap reliabilitas hanya dilakukan terhadap 37 responden. Pengambilan keputusan berdasarkan jika nilai Alpha melebihi 0,6 maka kuesioner tersebut reliabel dan sebaliknya (Ghozali,2006). Adapun hasil dari pengujian relibilitas adalah sebagai berikut :

Tabel 3. Hasil Pengujian Reliabilitas

\begin{tabular}{|l|c|c|}
\hline \multicolumn{1}{|c|}{ Variabel } & Nilai Alpha & Keterangan \\
\hline X1 (Due Professional Care) & 0,883 & Reliabel \\
\hline X2 (Akuntabilitas) & 0,765 & Reliabel \\
\hline Y (Kualitas Audit) & 0,866 & Reliabel \\
\hline
\end{tabular}

Berdasarkan tabel di atas terlihat bahwa variabel due professional care dan akuntabilitas memiliki status reliabel. Hal ini dikarenakan nilai Alpha Cronbach variabel tersebut lebih besar 
dari 0,6 . Kondisi ini juga memberikan arti bahwa seluruh variabel tersebut dapat digunakan pada analisis selanjutnya.

\section{Uji Asumsi Klasik}

\section{Uji Normalitas}

Uji normalitas bertujuan untuk menguji apakah dalam model regresi, variabel terikat dan variabel bebas keduanya mempunyai distribusi normal atau tidak. Distribusi normal akan membentuk satu garis lurus diagonal, dan ploting data akan dibandingkan dengan garis diagonal. Jika distribusi data adalah normal, maka garis yang menggambarkan data sesungguhnya akan mengikuti garis diagonalnya (Ghozali, 2006). Hasil scatter plot untuk uji normalitas adalah sebagai berikut :

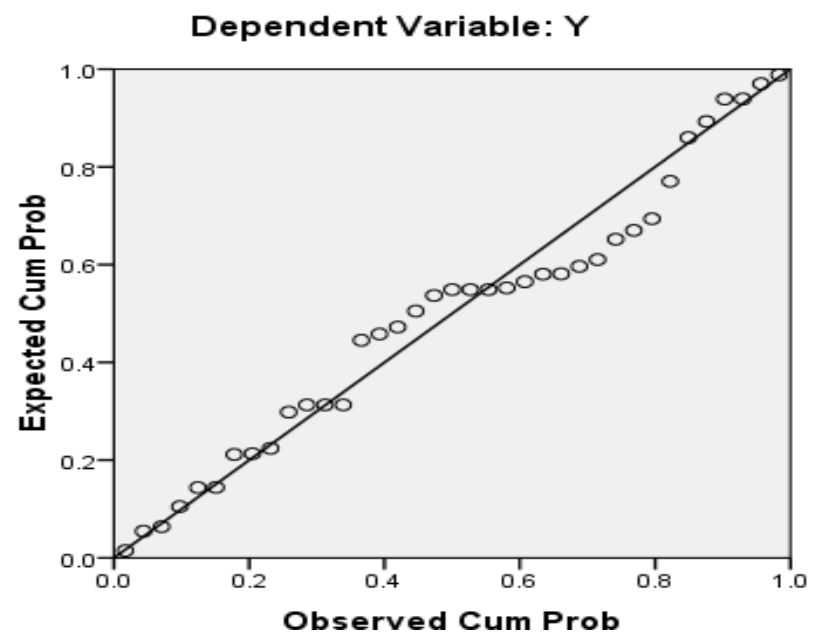

\section{Gambar 2. Hasil Uji Normalitas Data}

Jika dilihat berdasarkan grafik di atas, maka semua data terdistribusi normal. Hal ini karena semua mengikuti garis normalitas ditunjukkan dengan titik - titik yang tidak menjauhi garis diagonal.

\section{Uji Multikolinearitas}

Multikolinieritas adalah situasi adanya korelasi variabel-variabel bebas antara yang satu dengan yang lainnya. Ada tidaknya terjadi multikolinearitas dapat dilihat dari nilai VIF. Batasan nilai untuk dua variabel dikatakan berkolinearitas tinggi bisa dilihat melalui nilai VIF (Variance Inflation Factors). Apabila nilai VIF untuk variabel bebas lebih besar dari 10, maka salah satu diantara variabel yang berkorelasi tinggi tersebut harus direduksi dari model regresi (Raymond H.Myers, p 369).

Tabel 4. Hasil Pengujian Multikolinieritas

\begin{tabular}{|c|c|c|}
\hline \multirow{2}{*}{ Model } & \multicolumn{2}{|c|}{ Collinearity Statistics } \\
\hline & Tolerance & VIF \\
\hline 1 (Constant) & & \\
\hline $\mathrm{X} 1$ & .581 & 1.722 \\
\hline $\mathrm{X} 2$ & .581 & 1.722 \\
\hline
\end{tabular}


Dari Tabel 4 menunjukkan bahwa model regresi yang ada layak untuk dipakai dalam memprediksi kualitas audit. Hal ini ditunjukkan pada semua variabel bebas mempunyai nilai VIF yang berada jauh di bawah angka 10 sehingga dapat dikatakan semua konsep pengukur variabel-variabel yang digunakan tidak mengandung masalah multikolinieritas.

\section{Uji Heteroskedastisitas}

Imam Ghozali (2006) juga berpendapat bahwa uji heteroskedastisitas bertujuan menguji apakah dalam model regresi terjadi ketidaksamaan variance dari residual satu pengamatan ke pengamatan yang lain. Jika variance dari residual satu pengamatan ke pengamatan lain tetap, maka disebut homoskedastisitas dan jika berbeda disebut heterokedastisitas. Model regresi yang baik adalah yang homokedastisitas atau tidak terjadi heteroskedastisitas. Deteksi adanya heterokedastisitas dengan melihat ada tidaknya pola tertentu pada grafik, dimana sumbu $\mathrm{X}$ adalah Y yang telah diprediksi, dan sumbu X adalah residual (Y prediksi - Y sesungguhnya) yang telah di studentized. (Singgih Santoso, 2000), adapun grafik hasil uji heteroskedastisitas adalah sebagai berikut :

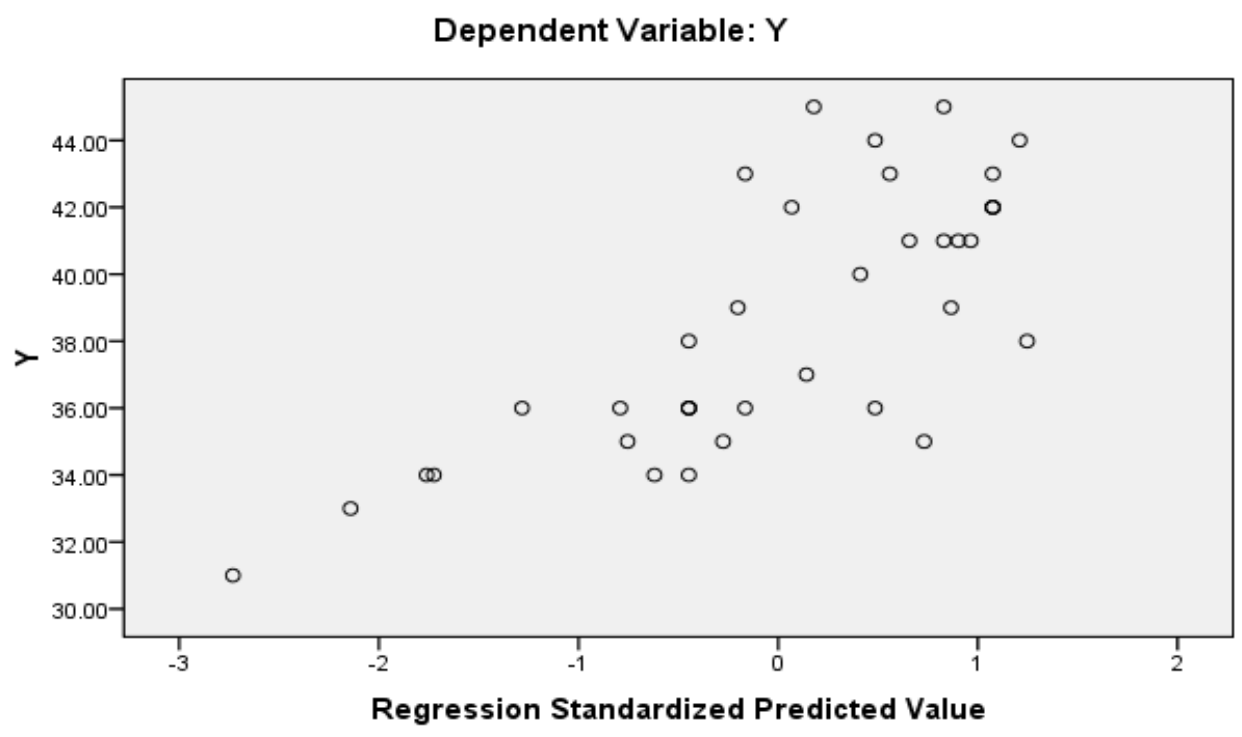

Gambar 3. Hasil Uji Heteroskedastisitas

Dari grafik Gambar 3 terlihat titik - titik menyebar secara acak, tidak membentuk suatu pola tertentu yang jelas, serta tersebar baik di atas maupun di bawah angka 0 (nol) pada sumbu Y. Hal ini berarti tidak heteroksidastisitas pada model regresi, sehingga model regresi layak dipakai untuk memprediksi Y.

\section{Pengujian Hipotesis}

Alat statistik untuk menguji hipotesis adalah regresi berganda (multi regression). Hal ini sesuai dengan rumusan masalah, tujuan serta hipotesis-hipotesis yang dilakukan dalam penelitian ini. Regresi berganda menghubungkan satu variabel dependen dengan beberapa variabel independen dalam suatu modal prediktif tunggal. Model regresi berganda yang digunakan dalam penelitian ini disajikan dalam persamaan berikut ini :

Keterangan:

$$
Y=\beta o+\beta_{1} X_{1}+\beta_{2} X_{2}+e
$$

Y $\quad=$ Kualitas Audit

Bo $\quad=$ Konstanta

$\beta_{1}, \beta_{2} \quad=$ Koefisien berganda

$\mathrm{X}_{1} \quad=$ Due Professional Care 


$$
\begin{array}{ll}
\mathrm{X}_{2} & =\text { Akuntabilitas } \\
\mathrm{e} & =\text { error }(5 \%) \text { dan signifikan }(95 \%)
\end{array}
$$

Pengaruh variabel independen terhadap variabel dependen diuji pada taraf signifikansi 5\%. Kriteria pengambilan keputusan dalam melakukan penerimaan dan penolakan setiap hipotesis adalah dengan membandingkan nilai t hitung dengan t tabel untuk masing-masing koefisien regresi. Apabila thitung lebih kecil dari t tabel, maka hipotesis nol (Ho) tidak dapat ditolak. Dan apabila $t$ hitung lebih besar dari nilai t tabel, maka Ho ditolak. Selain kriteria perbandingan $t$ hitung dengan $t$ tabel, juga digunakan kriteria nilai $\mathrm{p}$ value (kekuatan koefisien regresi dalam menolak Ho). Jika $p$ value $=0,05$ maka Ho ditolak dan apabila $p$ value $>0,05$ maka Ho tidak dapat ditolak.

\section{Analisis Regresi Linier Berganda}

Analisis statistik yang digunakan dalam penelitian ini yaitu regresi linier berganda Analisis ini digunakan untuk mengetahui besarnya pengaruh variabel - variabel bebas (independen) yaitu due professional care dan akuntabilitas auditor terhadap variabel terikat (dependen) yaitu Kualitas Audit. Besarnya pengaruh variabel independen yaitu due professional care dan akuntabilitas auditor dengan variabel dependen yaitu Kualitas Audit secara bersama-sama dapat dihitung melalui suatu persamaan regresi berganda. Berdasarkan perhitungan diperoleh hasil regresi sebagai berikut :

Tabel 5. Model Persamaan Regresi Berganda

\begin{tabular}{|c|c|c|c|c|c|c|c|c|c|c|}
\hline \multirow[b]{2}{*}{ Model } & \multicolumn{2}{|c|}{$\begin{array}{l}\text { Unstandardized } \\
\text { Coefficients }\end{array}$} & \multirow{2}{*}{$\begin{array}{c}\text { Standardized } \\
\text { Coefficients } \\
\text { Beta }\end{array}$} & \multirow[b]{2}{*}{$\mathrm{T}$} & \multirow[b]{2}{*}{ Sig. } & \multicolumn{3}{|c|}{ Correlations } & \multicolumn{2}{|c|}{$\begin{array}{l}\text { Collinearity } \\
\text { Statistics }\end{array}$} \\
\hline & B & Std. Error & & & & $\begin{array}{l}\text { Zero- } \\
\text { order }\end{array}$ & Partial & Part & Tolerance & VIF \\
\hline 1 (Constant) & 13.663 & 3.882 & & 3.520 & .001 & & & & & \\
\hline $\mathrm{X} 1$ & .605 & .225 & .399 & 2.689 & .011 & .677 & .419 & .304 & .581 & 1.722 \\
\hline $\mathrm{X} 2$ & .498 & .171 & .431 & 2.906 & .006 & .689 & .446 & .328 & .581 & 1.722 \\
\hline
\end{tabular}

Coefficients ${ }^{\mathrm{a}}$

a. Dependent Variable: Y

Berdasarkan tabel diatas, maka persamaan regresi yang terbentuk pada uji regresi ini adalah :

$$
Y=13,663+0,605 X_{1}+0,498 X_{2}+e
$$

Model tersebut dapat diinterprestasikan sebagai berikut :

a. Koefesien regresi variabel $\mathrm{X}_{1}$ (Due Professional Care) diperoleh sebesar 0,605 dengan arah koefesien positif. Hal ini menunjukkan bahwa due professional care auditor yang lebih tinggi dapat meningkatkan kualitas audit dalam pemeriksaan laporan keuangan.

b. Koefesien regresi variabel $\mathrm{X}_{2}$ (Akuntabilitas) diperoleh sebesar 0,498 dengan arah koefesien positif. Hal ini menunjukkan bahwa akuntabilitas auditor yang tinggi dapat meningkatkan kualitas audit dalam pemeriksaan laporan keuangan.

\section{Uji Signifikansi Parameter Individual (t-test)}

Uji t (t-test) dimaksudkan untuk mengetahui pengaruh secara parsial (individu) variabel - variabel independen yaitu Due Professional Care dan Akuntabilitas terhadap variabel dependen yaitu kualitas audit atau menguji signifikan konstanta variabel dependen. 
Tabel 6. Hasil Uji Signifikansi Parameter Individual (t-test)

\begin{tabular}{|c|c|c|c|c|c|c|c|c|}
\hline \multirow[b]{3}{*}{ Model } & \multicolumn{7}{|c|}{ Coefficients $^{a}$} & \\
\hline & \multicolumn{2}{|c|}{$\begin{array}{l}\text { Unstandardized } \\
\text { Coefficients }\end{array}$} & \multirow{2}{*}{$\begin{array}{c}\begin{array}{c}\text { Standardized } \\
\text { Coefficients }\end{array} \\
\text { Beta }\end{array}$} & \multirow[b]{2}{*}{$\mathrm{T}$} & \multirow[b]{2}{*}{ Sig. } & \multicolumn{3}{|c|}{ Correlations } \\
\hline & $B$ & Std. Error & & & & Zero-order & Partial & Part \\
\hline 1 (Constant) & 13.663 & 3.882 & & 3.520 & .001 & & & \\
\hline $\mathrm{X} 1$ & .605 & .225 & .399 & 2.689 & .011 & .677 & .419 & .304 \\
\hline $\mathrm{X} 2$ & .498 & .171 & .431 & 2.906 & .006 & .689 & .446 & .328 \\
\hline
\end{tabular}

Tabel 6, di atas dapat dilihat arah dan signifikansinya setiap variabel independen (due professional care dan akuntabilitas. Uji $\mathrm{t}$ dalam penelitian ini menggunakan cara membandingkan nilai $t_{\text {hitung }}$ dengan $t_{\text {tabel. }}$. Nilai $t_{\text {tabel }}$ dapat dilihat pada titik persentase distribusi $\mathrm{t}$, maka diketahui nilai $\mathrm{t}_{\text {tabel }}$ dengan $\mathrm{n}=37$ adalah 2,032. Hasil pengujian hipotesis masingmasing variabel independen secara parsial terhadap variabel dependennya dapat dianalisis sebagai berikut:

\section{a. Pengujian Hipotesis Pertama $\left(\mathrm{H}_{1}\right)$ Pengaruh Due Professional Care terhadap Kualitas Audit}

Berdasarkan hasil pengujian parsial (uji t) diperoleh nilai koefisien regresi sebesar 0,605 yang berarti variabel due professional care berpengaruh positif terhadap kualitas audit. Sedangkan nilai $t_{\text {hitung }}$ sebesar 2,689 , dimana $t_{\text {tabel }}$ sebesar $2,032<2.689$ menjelaskan bahwa variabel due professional care berpengaruh signifikan terhadap kualitas audit. Hasil ini menerangkan bahwa secara parsial variabel due professional care berpengaruh positif dan signifikan terhadap kualitas audit. Dengan demikian dapat disimpukan bahwa H1 diterima dan Ho ditolak. Artinya Due Professional Care yang lebih besar secara signifikan dapat meningkatkan kualitas audit.

\section{b. Pengujian Hipotesis ke dua $\left(\mathrm{H}_{2}\right)$ Pengaruh Akuntabilitas terahadap Kualitas Audit}

Berdasarkan hasil pengujian parsial (uji t) diperoleh nilai koefisien regresi sebesar 0,498 yang berarti variabel akuntabilitas berpengaruh positif terhadap kualitas audit. Sedangkan nilai $t_{\text {hitung }}$ sebesar 2,906, dimana $t_{\text {tabel }}$ sebesar 2,032<2,906 menjelaskan bahwa variabel akuntabilitas berpengaruh signifikan terhadap kualitas audit. Hasil ini menerangkan bahwa secara parsial variabel Akuntabilitas berpengaruh positif dan signifikan terhadap kualitas audit. Dengan demikian dapat disimpukan bahwa $\mathbf{H 2}$ diterima dan $\mathbf{H}_{\mathbf{0}}$ ditolak. Artinya akuntabilitas yang lebih besar secara signifikan dapat meningkatkan kualitas audit.

\section{c. Uji Signifikansi Simultan (F-Test)}

Uji statistik F atau Analisis Of Variance (ANOVA) pada dasarnya menunjukkan apakah semua variabel independen yang dimasukkan dalam model mempunyai pengaruh secara bersama-sama terhadap variabel dependennya. Nilai F dalam tabel ANOVA juga untuk melihat apakah model yang digunakan sudah tepat atau tidak. Hasil perhitungan uji $\mathrm{F}$ ini dapat dilihat pada tabel berikut ini : 
Tabel 7. Hasil Uji Signifikansi Simultan (F-test)

\begin{tabular}{|ll|r|r|r|c|c|}
\hline Model & & Sum of Squares & Df & Mean Square & F & Sig. \\
\hline 1 & Regression & 301.951 & 2 & 150.975 & 22.209 & $.000^{\text {a }}$ \\
& Residual & 231.130 & 34 & 6.798 & & \\
& Total & 533.081 & 36 & & & \\
\hline
\end{tabular}

a. Predictors: (Constant), X2, X1

b. Dependent Variable: $\mathrm{Y}$

Cara untuk menguji apakah model yang digunakan telah tepat atau belum terdapat dua cara, antara lain:

1) Membandingkan nilai $F_{\text {hitung }}$ dalam tabel ANOVA dengan $F_{\text {tabel }}$. Suatu pengaruh dikatakan signifikan jika $F_{\text {hitung }}$ lebih besar dari $F_{\text {tabel }}$. Nilai $F_{\text {tabel }}$ dapat dilihat dalam tabel $F$ pada alfa 0.05 dengan derajat bebas pembilang sebesar 3, atau dapat dilihat pada titik persentase distribusi maka diketahui nilai $\mathrm{F}_{\text {tabel }}$ dengan $\mathrm{n}=37$ adalah 3,276.

2) Cara lain untuk menguji apakah model dapat digunakan yaitu dengan membandingkan nilai Sig. pada tabel ANOVA dengan taraf nyatanya $(\alpha=0,05)$. Jika Sig. $>0,05$ maka model ditolak, namun jika Sig. $<0,05$ maka model diterima.

\section{d. Pengujian Hipotesis Ke Tiga $\left(\mathrm{H}_{3}\right)$ Pengaruh Due Professional Care Dan Akuntabilitas Secara Simulta Terhdapa Kualitas Audit}

Berdasarkan Tabel 7 yang diperoleh dari pengolahan, maka dihasilkan nilai $\mathrm{F}_{\text {hitung }} 22,209$

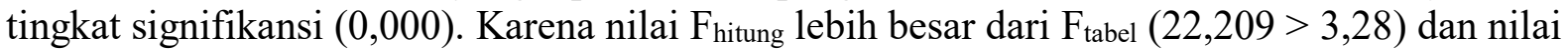
Sig. lebih kecil dari $0,05(0,000<0,05)$ maka model regresi tersebut diterima dan dapat digunakan untuk memprediksi pengaruh variabel independen terhadap variabel dependen secara simultan. Berdasarkan data dan hasil pengujian di atas, maka dapat disimpulkan bahwa "Due Professional Care dan Akuntabilitas secara simultan memiliki pengaruh positif dan signifikan terhadap Kualitas Audit”. Jadi, hipotesis ketiga yang diajukan H3 diterima dan $\mathbf{H}_{\mathbf{0}}$ ditolak.

\section{Kofesien Determinasi}

Uji Koefisien Determinasi untuk mengetahui besarnya sumbangan pengaruh variabel bebas (due professional care dan akuntabilitas) terhadap variabel terikat (kualitas audit) dalam bentuk persen yang dapat dilihat pada nilai Adjusted $R$ Square (R2).

Tabel 8. Koefesien Determinasi Model Summary ${ }^{b}$

\begin{tabular}{l|r|r|r|r|r|}
\hline Model & $\mathrm{R}$ & $\mathrm{R}$ Square & $\begin{array}{c}\text { Adjusted R } \\
\text { Square }\end{array}$ & $\begin{array}{c}\text { Std. Error of the } \\
\text { Estimate }\end{array}$ & Durbin-Watson \\
\hline 1 & $.753 \mathrm{a}$ & .566 & .541 & 2.60729 & 1.700 \\
\hline
\end{tabular}
a. Predictors: (Constant), X2, X1
b. Dependent Variable: $\mathrm{Y}$

Berdasarkan hasil perhitungan estimasi regresi, diperoleh nilai Koefesien Determinasi $\left(R^{2}\right)$ adalah 0,541 artinya $54,1 \%$ variasi dari semua variabel bebas seperti Due Professional Care dan Akuntabilitas dapat menerangkan variabel tak bebas yaitu kualitas audit, sedangkan sisanya $45,9 \%$ diterangkan oleh variabel lain yang tidak diajukan dalam penelitian ini. 


\section{Pembahasan}

Berdasarkan hasil analisis data diketahui bahwa variabel Due Professional Care dan Akuntabilitas secara individu dan bersama-sama berpengaruh signifikan positif terhadap Kualitas Audit.

\section{Pengaruh Due Professional Care Terhadap Kualitas Audit}

Adanya pengaruh positif dan signifikan sikap Due Professional Care auditor terhadap kualitas audit. Due professional care merupakan sikap penting yang harus diterapkan oleh seorang auditor dalam melaksanakan pekerjaannya agar tercapai kualitas audit yang memadai. Due professional care menyangkut dua aspek, yaitu skeptisme profesional dan keyakinan yang memadai (Elisha,2010). Hal ini menunjukkan bahwa indikator skeptis profesionalime yang besar serta keyakinan yang memadai yang diberikan Auditor dalam melaksanakan tugasnya mampu menghasilkan audit yang berkualitas.

Due Professional Care merupakan perwujudan sikap kritis seorang auditor terhadap bukti audit dengan selalu mempertanyakan dan mengevaluasi bukti audit tersebut. Penelitian ini konsisten dengan penelitian yang dilakukan oleh Putri Arsika dan Nur Cahyonowati (2013) membuktikan bahwa auditor yang mengimplementasikan due professional care dalam pekerjaan auditnya dengan baik, maka hasil audit yang dihasilkan akan makin berkualitas. Dari peryataan di atas dapat ditarik kesimpulan bahwa penggunaan kemahiran professional dengan cermat dan seksama (due professional care) akan memberikan pengaruh terhadap hasil audit yang dilaporkan oleh auditor.

Namun tidak sependapat dengan Saripuddin (2012) yang berpendapat bahwa Due Professional Care tidak berpegaruh signifikan terhadap kualitas audit. Sehingga Due Professional Care yang dimiliki auditor belum tentu meningkatkan kualitas audit yang dihasilkan.

\section{Pengaruh Akuntabilitas Terhadap Kualitas Audit}

Adanya pengaruh positif sikap akuntabilitas auditor yang berarti bahwa semakin tinggi sikap akuntabilitas seorang auditor, maka semakin berkualitas hasil auditnya. Hal ini menunjukkan bahwa indikator motivasi, pengabdian kepada profesi, dan kewajiban sosial yang kompleks dan cukup tinggi berpengaruh signifikan terhadap kualitas audit yang dihasilkan. Akuntabilitas merupakan perwujudan kewajiban seseorang atau organisasi untuk mempertanggungjawabkan pengelolaan sumber daya dan pelaksanaan kebijkan yang dipercayakan kepadanya dalam rangka pencapaian tujuan yang telah ditentukan.

Hasil penelitian ini konsisten dengan hasil penelitian yang dilakukan oleh Singgih dan Bawono (2010) yang mengatakan bahwa akuntabilitas berpengaruh secara parsial terhadap kualitas audit. Akuntabilitas merupakan perwujudan kewajiban seseorang atau unit organisasi untuk mempertanggungjawabkan pengelolaan sumber daya dan pelaksanaan kebijakan yang dipercayakan kepadanya dalam rangka pencapaian tujuan yang diterapkan.

\section{Pengaruh Due Professional Care Dan Akuntabilitas Secara Simultan Terhadap Kualitas Audit}

Pada pengujian hipotesis menunjukkan bahwa due professioanal care dan akuntabilitas auditor secara simultan berpenaruh terhadap kualitas audit. Pengaruh yang ditimbulkan adalah signifikan dan positif, yang artinya semakin tinggi tingkat due professional care dan akuntabilitas seorang auditor maka akan semakin tinggi pula kualitas hasil audit yang dihasilkan auditor tersebut. Hal ini menunjukkan bahwa indikator tepat waktu, lengkap, akurat, dan jelasnya hasil audit yang diberikan oleh seorang auditor akan berpengaruh positif dan signifikan terhadap kualitas audit yang dihasilkan auditor. Hasil penenlitian ini sejalan dengan hasil penelitian yang dilakukan oleh Singgih dan Bawono (2010) yang menguji apakah ada pengaruh independensi, pengalaman, due Professional Care dan akuntabilitas. Secara simultan 
terhadap kualitas audit. Hasilnya menunjukkan bahwa terdapat pengaruh yang signifikan terhadap variabel kualitas audit secara simultan atau bersama - sama.

\section{SIMPULAN DAN SARAN}

\section{Simpulan}

1. Due Professional Care auditor berpengaruh positif dan signifikan terhadap kualitas audit pada Kantor Inspektorat Provinsi Sulawesi Selatan, sehingga semakin tinggi tingkat Due Professional Care auditor maka akan semakin baik kualitas audit yang dihasilkannya.

2. Akuntabilitas auditor berpengaruh positif dan signifikan terhadap kualitas audit pada Kantor Inspektorat Provinsi Sulawesi Selatan, sehingga semakin baik akuntantabilitas auditor dalam melaksanakan tugasnya, maka akan semakin berkualitas audit yang akan dihasilkannya.

3. Due Professional Care dan Akuntabilitas auditor secara simultan berpengaruh positif dan signifikan terhadap kualitas audit pada Inspektorat Provinsi Sulawesi Selatan, sehingga semakin tinggi tingkat due professional care dan akuntabilitas seorang auditor maka akan semakin tinggi pula kualitas hasil audit yang dihasilkan auditor tersebut.

\section{Saran}

Berdasarkan hasil penelitian yang telah dilakukan maka diajukan saran, antara lain:

1. Untuk menigkatkan kualitas audit diperlukan adanya sikap due professional care yang tinggi yakni dengan peningkatan sikap cermat dan seksama serta peningkatan sikap kritis terhadap bukti audit. Hal ini dapat dilakukan dengan pemberian pelatihan-pelatihan dan peningkatan pendidikan profesi.

2. Para Auditor diharapkan untuk memiliki sikap akuntabilitas yang tinggi, karena faktor ini mempengaruhi kualitas audit. Auditor dalam melaksanakan tugas harus memiliki motivasi kerja yang tinggi, pengabdian pada profesi, dan kewajiban sosial.

3. Disarankan agar keterbatasan-keterbatasan yang ada pada penelitian ini dapat menjadi perbaikan bagi peneliti sejenis di masa yang akan datang.

\section{DAFTAR PUSTAKA}

Agustin, Aulia. 2013. Pengaruh Independensi, Pengalaman Dan Due Professional Care Terhadap Kualitas Audit. Jurnal Akuntansi. Vol 1, No.1

Alim, M. Nizarul, Trisni Hapsari, Lilik Purwanti. 2007. Pegaruh Kompetensi dan Independensi Terhadap Kualitas Audit Dengan Etika Auditor Sebagai Variabel Moderasi. SNA $X$ MAKASSAR

Arens, Alvin A, Randal J. Elder, Mark S. Beasley. 2008. Auditing dan Jasa Assurance: Pendekatan Terintegrasi. Edisi Keduabelas. Erlangga. Jakarta.

Christiwan, Yulius Jogi. 2002. Kompetensi dan Independensi Akuntan Publik: Refleksi Hasil Penelitian Empiris. Jurnal Akuntansi dan Keuangan. Vol. 4. No. 2.

DeAngelo,L.E.1981. Auditor Size and Audit Quality.Journal of Accounting and Economics. 3 (1981) 183-199.

Ghozali, Imam.2006. Aplikasi Analisis Multivariat Dengan Program SPSS. Semarang: BP Undip.

Hidayat, M Taufik. 2011. Akuntabilitas Auditor Dan Profesionalisme Auditor Terhadap Kualitas Auditor. Skripsi. Fakultas Ekonomi Universitas Diponegoro Semarang. 
Hutabarat, Goodman.2012.Pengaruh Pengalaman, Time Budget Pressure dan Etika Auditor terhadap Kualitas Audit. Jurnal Ilmiah ESAI. Volume 6, No. 1

Kumaat, Valery G. 2011. Internal Audit.Edisi Terbaru. Erlangga. Jakarta

Mardisar, Diani dan Ria Nelly Sari. 2007. Pengaruh Akuntabilitas dan Pengetahuan terhadap Kualitas Hasil Kerja Auditor. SNA X Makassar. AUEP-11.

Munawarah, Siti.2019. Pengaruh Independensi dan Motivasi Terhadap Kualitas Audit pada Kantor Inspektorat Kabupaten Berau. Jurnal of Economic, Management and Accounting. Volume 2 Nomor 1, Maret 2019

Nirmala,P. Arsika, Cahyonowati Nur. 2013. Pegaruh Independensi, Pengalaman, Due Professional Care, Akuntabilitas, Kompleksitas Audit, dan Time Budget Pressure terhadap Kualitas Audit. Diponegoro Journal Of Accounting. Vol 2, No.3.

Nugraha, A Basit Fauzi. 2011.Pengaruh Independensi, Pengalaman Dan Due Professional Care Terhadap Kualitas Audit. Skripsi. Jurusan Akuntansi Universitas Komputer Indonesia

Rapina, Saragi, Lili Marlen, Carolina Verani. 2010. Pengaruh Independensi Eksternal Auditor Terhadap Kualitas Pelaksanaan Audit .Akurat Jurnal Ilmiah Akuntansi . No.2 Tahun Ke1 Mei-Agustus 2010

repository.unhas.ac.id/.../proposal\%20sempurna\%20acc\%201.docx?.Tanggal Download, 29$11-2013.18: 49$

Riani, Febri. 2013. Pengaruh Pengetahuan Audit, Akuntabilitas Dan Independensi Terhadap Kualitas Hasil Kerja Auditor. Skripsi. Program Studi Akuntansi. Fakultas Ekonomi . Universitas Negeri Padang

Salsabila, Ainia, Prayudaiwan. 2011.Pengaruh Akuntabilitas, Pengetahuan Audit Dan Gender Terhadap Kualitas Hasil Kerja Auditor Internal. Jurnal Telaah \& Riset Akuntansi.Vol 4. No.1.

Saripuddin, Herawaty Netty, dan Rahayu. 2012. Pengaruh Independensi, Pengalaman, Due Professional Care dan Akuntabilitas Terhadap Kualitas Audit. E-Journal BINAR AKUNTANSI .Vol.1, No.1.

Singgih, E. Muliani, Icuk Rangga Bawono. 2010. Pengaruh Independensi, Pengalaman, Due Professional Care dan Akuntabilitas Terhadap Kualitas Audit. SNA XIII Purwokerto.

Sugiyono. 2010. Metode Penelitian Kuantitatif Kualitatif. Alfabeta . Bandung

Umar, Husein.2005. Motode Penelitian untuk Skripsi dan Tesis Bisnis. Edisi ke-7. PT Raja Grafindo Persada.Jakarta. 